A peer reviewed open access journal indexed in NepJol; ISSN 2542-2596

Published by Molung Foundation, Kathmandu, Nepal

Article History: Received on 16 March 2021; Accepted on 30 May 2021

DOI: $\underline{\text { https://doi.org/10.3126/mef.v11i0.37834 }}$

\title{
Linked Lives: Exploring the Narratives of Second-Generation Migrants in Nepal \\ Chhabilal Devkota $^{1}$ and Sanjeev Dahal ${ }^{2}$ \\ ${ }^{1}$ Adharsheela College, Sorakhutte, Nepal \\ ${ }^{2}$ Boston College, MA, USA
}

\begin{abstract}
Author Note
Chhabilal Devkota is a student of Social Work who conducted this research for his thesis in partial fulfilment of his Master's degree in Social Work from Tribhuvan University.

Sanjeev Dahal (D https://orcid.org/0000-0001-5571-1043 is a Ph.D. student in Social Work at Boston College, Massachusetts, USA and supervised Devkota's Master's thesis. The data for this paper was obtained from the multicountry research project "Linked lives": Culture, space and identity among adult children of first-generation migrants across Nepal, Norway, South Africa and the UAE; Dahal coordinated the research project in Nepal.

Correspondence concerning this article should be addressed to Sanjeev Dahal, 140 Commonwealth Avenue, Chestnut Hill, MA 02467, United States. Email: dahalsanjeev@gmail.com
\end{abstract}




\begin{abstract}
This article describes the narratives of second-generation migrants in Nepal. The paper explores the reasons for migration as shared with their offspring by firstgeneration migrants. The article also shares the narratives by second-generation migrants on experiences of family, school, community, and the State. Secondgeneration migrants or adult offspring of first-generation migrants from Tibet and India comprised the sampling frame for the qualitative study. Data were collected through a non-probability sampling technique, and in-depth semi-structured interview schedules were used. Nine in-depth interviews were conducted for the study. Thematic analysis was employed to examine the data. Key reasons to migrate to Nepal featured in the narratives of the migrants were opportunities for business, availability of good education, and a suitable climate in Nepal.

Furthermore, lack of opportunities for employment and education and instances of violence at their place of origin pushed the migrants towards Nepal. Most of the interviewees shared having solid bonds with their families. They shared mixed experiences (both encouraging and humiliating) at school and varied experiences in their interaction with the broader society (both supportive and conflicting). Furthermore, all interviewees shared challenges in dealing with or receiving help from the Nepali State.
\end{abstract}

Keywords: migration, Nepal, children of immigrants, migrant experiences in Nepal, second-generation migrants 


\section{Linked Lives: Exploring the Narratives of Second-Generation Migrants in Nepal}

Migration is a dynamic concept and involves various forms of population mobility (Sharma \& Sharma, 2011). Kok (1997) defines migration as crossing the boundary of a predefined spatial unit by one or more persons, resulting in the change of residence. Institute of Migration [IOM] (2019a) reiterates that migration is "The movement of persons away from their place of usual residence, either across an international border or within a State" (p. 137). Migration also involves decision-making about moving, the act of moving, and a process whereby people adapt to a new environment (Virupaksha et al., 2014).

The share of international migrants in the world population has increased from 2.3 percent in 1980 to 2.8 percent in 2000 and to 3.6 percent in 2020 (Global Migration Data Portal, 2019). The International Organization for Migration (IOM, 2019a) describes that a migrant is

any person who is moving or has moved across an international border or within a State away from his/her habitual place of residence, regardless of: (1) the person's legal status; (2) whether the movement is voluntary or involuntary; (3) what the causes for the movement are; or (4) what the length of the stay is. (para.1)

The number of migrants in the world who lived outside their country of origin in 2019 was 272 million, increasing from 258 million in 2017 (Global Migration Data Portal, 2019). Migration as a phenomenon has drawn considerable interest worldwide because of its omnipresence and its impact on the world that we know today. In this regard, the United Nations has dedicated enough attention to migration in its Sustainable Development Goals [SDGs], where 11 out of the 17 SDGs contain targets and indicators relevant to migration or mobility. The core principle of SDGs is to 'leave no one behind,' not even migrants (Global Migration Data Portal, 2019). 
Migration is generally perceived to be a complex phenomenon because of the multiple complexities it may involve, e.g., differences in languages, food habits, clothing patterns, religious beliefs and practices, cultures, to name a few, between origin and destination. Migration is a complex phenomenon also because of the varied experiences of migrants as they migrate with their culture and cultural capital. Bhugra et al. (2020) draw attention to the vital role of cultural capital in acculturation and in reduction of distress after migration.

Ample discussion has been made around the phenomenon of migration, including the reasons for migration. Shrestha (1990) and Virupaksha et al. (2014) discuss migration as a path to financial freedom and bring attention to capitalism as a reason for domestic and international migration. Wolpert (1965), in the 'situational approach,' says that people migrate when the value of 'place utility' of a location is more significant than other locations. For Wolpert, the value of place utility involves social, economic, and other costs and benefits that the person gets in a particular location. Joseph (1988) contends that migration frequently occurs due to socio-economic-political changes. Lee (1966) forwards the much-acclaimed 'push-pull theory' of migration. The 'push-pull theory' lists several factors that push people from their place of origin and the factors that lure people to the place of destination. Some examples of push factors are war, natural disasters like famine, flood, landslide, and examples of pull factors are better education, better social protection systems, and better employment opportunities.

Emigration is a prominent phenomenon in Nepal, and extant poverty and lower human development indicators provide fertile grounds for emigration. The Department of Foreign Employment in Nepal flags that nearly 1400 Nepalese left Nepal every day between 2018 and 2019 to work elsewhere (Mandal, 2019).

Poverty is a major reason for the emigration of Nepalese. Based on the Multidimensional Poverty Index 2016 data, “34.0 percent of the population were multidimensionally poor while an additional 22.4 percent were classified as 
vulnerable to multidimensional poverty" (United Nations Development Program, 2020 , p. 6). However, immigration to Nepal is considerably smaller and has received little attention from scholars. According to the 2001 census, there were 116,571 foreign-born citizens in Nepal; $90 \%$ of them were of Indian origin, followed by those with origins in Bhutan, Pakistan, and China (Central Bureau of Statistics, 2011). Similarly, the 2011 Census shows approximately 1.8 percent of the total population in Nepal to be foreign-born, with 93.6 percent born in India (IOM, 2019b). IOM (2019b) states that foreign-born citizens primarily stayed in Nepal because of marriage (45.8\%), dependents (17\%), and business.

Against the backdrop of little scholarly attention on the phenomena of immigration in Nepal and migration-related experiences, this paper discusses the narratives of the adult offspring of first-generation migrants, defined as secondgeneration migrants, in Nepal. The paper primarily brings out the reasons for migrating to Nepal as shared by these second-generation migrants. The paper also looks into the experiences of living in Nepal as shared by these migrants. The general objective of the paper is to bring out the narratives of second-generation migrants in Nepal. The specific objectives of the paper are a) to explore the causes of migration to Nepal, and b) to investigate the experiences of secondgeneration migrants to Nepal.

\section{Research Methodology}

The study intended to explore the reasons for migration for the firstgeneration migrants to Nepal and to understand the experiences of the adult offspring of these first-generation migrants or the second-generation migrants. Qualitative methodology was chosen to explore the overall experiences of the respondents. In the absence of studies surrounding emigration and the experiences of emigrants, the study used an exploratory design where semi-structured interviews were conducted with all the respondents. The study used nonprobability sampling, including snowball sampling and purposive sampling, to 
collect data. Snowball sampling helped locate the lesser known population or hard to locate population of emigrants and purposive sampling allowed for inclusion of emigrants from both Tibet and India. Nine interviews were conducted in Kathmandu between 2017 and 2018. All the interviewees were adults whose parents had migrated to Nepal from other countries. The demographic information on the interviewees is provided in Table 1 below. The narratives shared by the interviewees were based on memory or recall. Some questions asked during the interviews are: Tell me the story of your parents leaving the country of origin and coming to this country; what have they told you about their reasons for migrating? When did they migrate?; Can you tell me about your parents and your relationships with friends/family in the country of origin?; Tell me about your schooling, relationships with teachers, friends, family as a child growing up in this country.

In-person interviews were conducted at respondent's convenient location and were audio-recorded. Interviewees could choose to respond in English, or Nepali language, whichever was comfortable to them. Most respondents used both languages, sometimes mixing Nepali and English in a single sentence. The recorded interviews were transcribed verbatim and then translated into English. Thematic analysis was then employed to look into the interview transcripts. The six-phase approach to Thematic Analysis recommended by Braun and Clarke (2012) was used; it involved familiarization with the data, generating initial codes, searching for themes, reviewing potential themes, defining and naming themes, and producing the report. Ethical consideration by the study included anonymity of the interviewees (use of pseudonyms), informed consent (obtaining oral as well as written informed consent), professional competence (conduction of interviews by trained personnel), respect for people's right, dignity and diversity. Voluntary participation and the principle of non-violence-do no harm-were also implemented in the study. 


\section{Table 1}

Demographic Composition of the Respondents

\begin{tabular}{|c|c|c|c|c|c|c|}
\hline Name & Age & Sex & Education & $\begin{array}{l}\text { Family's } \\
\text { Occupation }\end{array}$ & Origin & Religion \\
\hline Akash & 25 & M & $\begin{array}{l}\text { Bachelor in } \\
\text { Engineering }\end{array}$ & Business & India & Hindu \\
\hline Agya & 18 & $\mathrm{~F}$ & +2 & Business & India & Hindu \\
\hline Priti & 43 & $\mathrm{~F}$ & Bachelor & $\begin{array}{l}\text { Healer/ } \\
\text { Instructor }\end{array}$ & India & Hindu \\
\hline Roshani & 18 & $\mathrm{~F}$ & $\begin{array}{l}\text { Bachelor in } \\
\text { Journalism }\end{array}$ & Business & India & Hindu \\
\hline Shanti & 21 & $\mathrm{~F}$ & $\begin{array}{l}\text { Bachelor of } \\
\text { Arts running }\end{array}$ & Teacher & India & Hindu \\
\hline Anamika & 40 & $\mathrm{~F}$ & $\begin{array}{l}\text { Bachelor of } \\
\text { Arts }\end{array}$ & Business & India & Hindu \\
\hline Kartok & 25 & $\mathrm{~F}$ & $\begin{array}{l}\text { Bachelor of } \\
\text { Arts }\end{array}$ & Monk & Tibet & Buddhist \\
\hline Pema & 22 & $\mathrm{~F}$ & $\begin{array}{l}\text { Bachelor of } \\
\text { Arts }\end{array}$ & $\begin{array}{l}\text { Retired } \\
\text { Army }\end{array}$ & Tibet & Buddhist \\
\hline Lek & 22 & M & $\begin{array}{l}\text { Bachelor in } \\
\text { Business } \\
\text { Studies }\end{array}$ & & Tibet & Buddhist \\
\hline
\end{tabular}




\section{Theoretical Framework}

This paper primarily uses two theoretical frameworks, namely Lee's (1966) push and pull factors of migration and Life-course Perspective, particularly its central proposition of Linked Lives. Lee's (1966) push and pull factors of migration provided a clear direction to describe the data brought out by the narratives of the second-generation migrants to Nepal, particularly what factors were instrumental in pushing migrants from India and Tibet to Nepal and what factors appealed to them to migrate to Nepal. Linked lives is a notion that "people in salient relationships with each other, such as parents and children, occupy mutually influential interlocking developmental trajectories that extend throughout their lives" (Elder et al., 2003 in Greenfield \& Marks, 2006, p. 2). The notion of linked lives was amply featured in the narratives of the secondgeneration migrants to Nepal who were influenced by the stories of migration of their parents and in their sharing of experiences at school, including relationships with their peers and teachers.

\section{Findings and Discussions}

This paper brings out the reasons for migration for first-generation immigrants from India and Tibet to Nepal, as shared through the narratives of the second-generation migrants. Additionally, it features the everyday experiences of second-generation migrants, namely experiences within family life (including the relationship with family members), experiences at school (including the relationship with their peers and teachers), and experiences in the community (including cultural and religious similarities and differences and struggles with the Nepali language).

\section{Reasons for Migration}

The interviewees shared several reasons for coming to Nepal. These included opportunities for business, opportunities for a good education, a suitable climate and culture, opportunities to earn a livelihood and build a career. Also, 
lack of opportunities and instances of violence at their place of origin was reported to move into Nepal. The reasons for migration shared by the interviewees can be categorized as push and pull factor according to Lee's suggestion (1966).

\section{Pull Factors}

Opportunities for business were mentioned by five of the interviewees as reasons to migrate to Nepal. The excerpts below share some of these:

My mom and dad decided to go to Nepal, and my dad actually got a business offer here. So he decided to come. (Roshani)

The primary reason for their coming was making a good living here... They were originally from Rajasthan in India. My father used to work in Bombay when one of his friends suggested going to Kathmandu for work. In the beginning, he did a job here in Kathmandu. Later, after 7 or 8 years, he started his own textile business. (Priti)

The primary motivation to migrate was economic. My parents were originally from Rajasthan. They ran a small textile business there, but the earning was not so good. So, they decided to come to Nepal for business. (Anamika)

After giving up farming, he [my father] came to Kathmandu to visit our relatives. After coming here, he felt that there was a business opportunity here. (Akash)

The data reflects that quality education is another important factor influencing migration to Nepal. Three interviewees shared 'good education opportunity' as pull factors to migrate to Nepal, as mentioned in excerpts below:

We used to stay in a small city near Delhi. Everything was good there, but there was not much exposure to better education system. (Roshani) They [my parents] wanted to make a good living for them as well as their children. Another reason was the education of their children. Rajasthan 
didn't have good schools back then. So, they were also looking for educational opportunities for their children when they decided to come here. (Anamika)

Our family was the lord of lands which was why I was allowed into a boys' school. But I was the only girl in the entire school... So my father thought that if they came to Nepal children would have the opportunity for better education and exposure. (Priti)

Besides opportunities for business and education, other pull factors to Kathmandu shared by the interviewees were its cool climate, cultural openness, natural beauty, and religious harmony as shared below:

Kathmandu is popular among Indians, both from cultural perspective and climatic perspective. (Akash)

[My father says] Nepal was beautiful. Food was good. Environment was nice. Culture was nice. Even when people were working they cared for the others too. (Lek)

They [Kartok's parents] came to Nepal for pilgrimage once before settling here. The reason they chose Nepal was that it was a peaceful country with lots of religious places for Buddhism. (Kartok)

\section{Push Factors}

According to Lek, the religious issues of Tibet forced their parents to migrate to Nepal.

I think my father left because of difficulty. It is the story of 1959 A.D. My grandfather was in the special force that protected His Holiness Dalai Lama. So, he had to flee Tibet. (Lek)

Shanti shared that her family migrated to Kathmandu due to the unsuitable climate of Calcutta, India. Shanti stated, "My dad never liked the weather of Calcutta. My mom and dad grew up in Manipur, and in Nagaland respectively; 
their families migrated to Calcutta and both of them did not enjoy the weather there".

The data reveals that Indian immigrants mainly migrated for business purposes whereas Tibetan migrants primarily escaped from unstable politics. These findings support Lee's push and pull factors of migration. Few Indians and Tibetans stayed in Nepal and started liking the weather and its natural beauty and the openness of the Nepalese. This motivated them to extend their stay in Nepal which turned into permanent residence for some of those visitors.

Wolpert (1965) emphasized 'place utility' in his theory 'the situational approach' where people have a higher value of the chosen location rather than other places. The term 'place utility' involves social, economic, and other costs and benefits that the person gets in a particular location. The findings of this study highlights 'place utility' for both Indian and Tibetan immigrants; for Indians, fertile land for business was a major utility, while safety and refuge from the War in Tibet provided utility from Tibetan immigrants to Nepal. In the historical approach, Joseph (1988) says that migration occurs from time to time due to the pressures and counter-pressures both from the internal and external sources and due to the structural transformation of socio-economic and political setup. The findings of the study are along these lines where the political instability of Tibet was a significant reason to leave Tibet for Nepal (pressures from the political set up). Opportunities for socio-economic transformation for Indian migrants were reported as significant reasons for migration.

\section{Experiences of Second-generation Migrants in Nepal}

In addition to the reasons for migration shared in the narratives of the second-generation migrants in Nepal, the paper also features the everyday experiences of second-generation migrants, namely experiences within family life, experiences at school, and experiences in the community and the State, which are detailed below. 


\section{Experiences Related to Family}

Six interviewees shared having strong bond with relatives and one interviewee hinted towards conflict in their relationship while discussing family relations. Various aspects of family relationships, including sharing time with relatives, visiting the place of origin, frequent chats, and telephonic conversations with grandparents, were discussed in these narratives. Additionally, attending social and religious ceremonies, enjoying vacation, building a strong bonding with, and having fun with cousins were featured in the narratives too.

Technological development and access to social media were chiefly mentioned as factors facilitating a strong positive relationship between immigrants and their relatives.

Because calls were expensive: especially international calls, communicating with each other was only done to inform about events like marriage or other events. Now technology has made communicating easier. We talk more often and are connected to everyone through social media. (Akash)

Even though we are far in terms of geography, technology has brought everyone together. (Agya)

Another aspect of their lives that the second-generation migrants to Nepal enjoyed talking about was their strength and family prominently featured in their narratives. Second-generation migrants believed that these strengths led them to success in the host country, Nepal. For Shanti, "Self-motivation, self-trust, and individualization are biggest strength," and Agya emphasized on self-confidence as strength. She stated, "We have the confidence to travel. As long as we have money, the passport, and the phone, you can travel anywhere". Two interviewees shared that family or their parents were their biggest strengths, as seen below:

My friends and family are my biggest strengths and support system. (Agya) 
My father always told us that every problem has solution, and we should keep striving for it. I believe in what he said. (Priti)

The nature of parents was also identified as the strength of the family and source of inspiration, as seen below:

We Tibetans bow down to people often; my father has a good way of talking to people. He is very respectful. Because of my parents' good behaviour, people treat me well too. We [Tibetans] are helpful people. (Lek)

Even though they [her parents] didn't have anyone behind them, they believed something was behind them. They are very adjusting even in adverse family situations. The struggle that I faced taught me to look at things differently. (Kartok)

\section{Experiences Related to School}

Experiences related to school occupied significant space in the narratives of the respondents. The key themes that emerged in these narratives were difficulty in language and relationship with peers and teachers, both of which are discussed at length below.

Difficulty in Language. Language difficulty was the most frequently described experience by the interviewees while in Nepal as the Nepali language is the primary language in schools - which was different from their mother tongue and communicating language. Although speaking in English was encouraged in classrooms, Nepalese students ubiquitously talked in Nepali, which created difficulties for second-generation migrants. Presented below are some excerpts from interviews regarding the difficulties in language:

My mother tongue is Hindi, so an accent came when I spoke Nepali" (Akash)

Studying in a government school, where the primary medium of instruction in the Nepali language was another huge challenge for me. I 
could not communicate in Nepali well. It was a very difficult phase for me. In Rajasthan we only spoke Marwadi language, not even Hindi. I was depressed in school. But one of my friends helped me a lot. Her name was Sonika Maharjan [name changed]. She used to watch Hindi movies and read Hindi comics. So, she knew the Hindi language. And she was the one who taught me Nepali. (Priti) In initial days, we used to talk in sign language. Language was a barrier. As for now, they [her parent] are equipped with basic Nepali language to use in markets. (Kartok)

We had to study Tibetan, but we also studied all subjects in the curriculum of Nepal Government... We speak a little Nepali but there are others who do not speak much. Most of the Tibetan students fail in Nepali but they pass in other subjects. In the place I live, all are Tibetans, so we all speak Tibetan. We only have to speak Nepali at shops or at college or in the public transportation. (Lek)

Kartok shared having to speak in Nepali in college and using the Tibetan language in her house and camp. So she experienced difficulties in adjusting between the two languages. The analysis reveals that the everyday life experiences of Tibetan migrants are more complex than those of the Indian migrants. One of the reasons might be that majority of the Nepalese can understand Hindi but not the Tibetan language. Access to Indian schools to children of Indian immigrants opens an environment to talk and share in their mother tongue if needed. Although there were Tibetan teachers in Tibetan schools, one of the respondents shared that they hesitated to speak with the Tibetan teachers. Communication assists immigrants in satisfying their basic personal and social needs in the new host culture and facilitates acculturation (Lakey, 2003). Yun Kim (1979) suggests that humans can adapt, and immigrants acculturate themselves to receive and interpret messages in a way that they will be 
recognized, accepted and responded to by the individual or group with which they interact. Along these lines, the interviewees shared that it grew easier for them to adapt to the new Nepalese culture after they started speaking Nepali.

Relationship with Peers and Teachers. Besides the struggles with language, interviewees shared fond memories of school life. Eight of the nine interviewees shared having a close relationship with at least one of the teachers. Some shared:

We had nice and friendly teachers. I had a teacher. Her name was Rima [name changed] and she was very friendly. I miss her. I still talk to her sometimes. (Agya)

The experience at school was good...Most students were Tibetans..... I

liked the Nepali teachers too, they were learning about Tibetan culture. They understood us. (Lek)

Some of the interviewees mentioned having a 'favorite teacher' in their school life. Favorite teacher, for them, was supportive, helpful, kind, and generous, as seen in the sayings below:

I was a teacher's pet. I still remember Pabita ma'am [name changed] from Triyog School, my class one class teacher. Up to date, she is my favourite teacher. I also liked Soniya ma'am [name changed] -class teacher at class 3. I have not forgotten their names. (Shanti)

I knew every teacher, and they were very good and supportive. My math teacher was my class teacher when I was in class 6 , and he used to support me every time. When I was humiliated [at school by a friend], I used to cry, and he used to call me and tell me things will get better. He said he would talk to her [my friend who humiliated me], so he was very encouraging, very good. (Roshani)

One respondent also mentioned ethnicity-based affinity while at school. She shared: 
What I noticed was like I am Indian and if the teachers had Indian origin, automatically you feel apnapan, aafnai jasto lagney, and [feeling of intimacy] because they face the same thing in the country and they know what I face. (Shanti)

All the respondents who went to residential Tibetan schools shared being isolated from the outer environment and having limited interaction with the community, as shared in the excerpt below:

I think that there is a difference between people who went to Namgyal [residential Tibetan school] and those who went to other schools. I feel the others who went to other schools have more knowledge on subjects and faculties... We stay in hostels and do not know much about what's happening outside of the camps as we went out once a month. But we do learn a lot of skills while at school. (Lek)

Like Lek, other interviewees of Tibetan origin also shared receiving life skills at school, which they felt helped them in their everyday life at school and beyond. They mainly talked about taking leadership positions at school, which allowed them to become independent. For example, Pema was active in the school in different roles: class captain, house captain, and vice-president of the student council. She shares how she lifted herself to lead a march that was led only by boys before her:

The march pass was very competitive during the sports day. .... Everyone wanted to win. The leading person of the March pass were boys every time. In my final year, I told my house teacher that I wanted to lead the march. He agreed, but my statement shocked everyone. Very few people believed me. I proved them wrong. We won the march pass. Even judges were impressed to see girls leading the march. I left the high school setting examples of gender equality. (Pema) 
Sometimes second-generation migrants faced difficult experiences in school. Roshani and Shanti shared feeling humiliated at school: there was a Nepali girl in the same class, who used to humiliate me, and keep me away from socializing and befriending other people in the class...whenever I tried to befriend anyone in the class, she would tell me I cannot be friends with that person, because that person is her friend since a long time, and I was only a newcomer. This was in my first year in Nepal, that phase was challenging. I used to make every possible excuse like headache and stomach upset to skip school. I literally used to vomit to show my parents that I am not feeling well. (Roshani)

I faced that 'Dhoti' [a derogatory term to denote Indians] term a lot in school life. (Shanti).

\section{Experiences Related to the Community and State}

The experiences of the interviewees within the community and the State were diverse and sometimes contradictory. While some interviewees shared being treated well and getting supportive hands in Nepal, some others shared experiences of humiliation. These diverse experiences with the broader community are shared below.

Community-related Experiences. The interviewees shared mixed responses regarding their experiences with the broader community in Nepal. Two interviewees of Tibetan origin shared that they saw similarities between communities in Nepal and Tibet; this helped them build good relations with the Nepalese. Pema somewhat identified with the Newar community in Kathmandu and expressed, "I never felt myself different than others...I had a bit of Newari background and [I am] pretty sound in the Nepali language. It was normal for me to settle." Lek compared 'Kham' with 'Gorkhali' as both are popular for their commitment and trustful behaviour. He emphasized, "People in Kham are simplestraightforward. Many are in the Army. They don't like when people cheat. But 
when they are friends, and they like you, they will give their lives for you," and he felt similarly about the Gorkhalis in Nepal. In the contrary, some of the respondents with origins in India shared being name-called, as expressed below:

I think nobody should be treated on the basis of what caste or community they come from. Your treatment of another person should be solely guided by how that person treats you. I am still pinched by such name 'Madey' [a term used to refer to Marwaris derogatorily]. (Priti)

Two other respondents, also with origins in India, shared relying on Nepali friends for many things, including emotional support and support to earn a livelihood. Priti expressed:

I wanted to open a boutique in Kathmandu. But I couldn't do so with an Indian citizenship. And my friend Ranju [name changed] helped me. I opened the boutique in her name and ran it for two years.

And Shanti shared that she relied on friends, teachers, and family rather than diplomatic missions for emotional support. She expressed, "Embassy doesn't help at the emotional level. It helps if there are any issues related to the government; they help at the level of law or advocacy."

State-related Experiences. All interviewees with Tibetan origin shared difficulties in government-related works in Nepal and not getting supportive treatment from the Chinese Embassy. The interviewees of Tibetan origin reiterated being under close surveillance from the Government of China and being restricted by the Nepal government to do any activities against China. According to Tibetan interviewees, running public activities became increasingly difficult after 2008 A.D., and they limited their activities within the camp. And that too was being scrutinized by the Nepal Police, who demanded that any celebrations inside or outside the camps be done with their consent. The interviewees shared: 
We cannot celebrate our important days, like Democracy Day and other ceremonies in public. Earlier we used to have such celebrations. Now it is very strict...Even within the camps, the police had come last time. (Lek) Since 2008, we haven't had the opportunity to celebrate the birthday of $\mathrm{H}$. H. Dalai Lama peacefully. Even on March 10 [Tibetan Uprising day], Nepalese police guard the Boudha, every Tibetan settlement area, to not perform any activities against the Chinese. They don't even let us go out of the settlement or area. You are put into jail if you wear traditional Tibetan attire during these days. (Pema)

The political atmosphere and changes can also impact the immigrants in the host nation, as can be seen in immigrants of both Indian and Tibetan origin in Nepal. Such impacts gain prominence at times. An example of this includes antiIndian protests during the 2015 undeclared blockade of Nepal by India. Bhugra (2004) asserts that one's identity comprises the racial, cultural, and ethnic identities. The ethnic identity of being an Indian in Nepal at times like the 2015 blockade impacted the lives of immigrants from India in Nepal. Akash shared:

I remember that I was unemployed during the time of blockade and was looking for a job. I went to some interviews. Most of them were fine by me being an Indian citizen, but some of them - the moment they found out that I am an Indian - they got reluctant to offer me the job. (Akash)

Citizenship is an important document that proves an individual's identity, and the process of obtaining Citizenship also speaks volumes about the way the state treats individuals. The data analysis reveals that two interviewees had Indian Citizenship; two had Nepali Citizenships; one of the interviewees had a Nepali passport, and another had two Citizenships (one from Nepal and the other from India). Furthermore, one of the interviewees neither had a Citizenship nor a Tibetan refugee card, and two respondents did not disclose their Citizenship status. Each respondent had an interesting story to share regarding Citizenship. 
Interviewees with Tibetan origin shared paying large amounts of money to get Citizenship, and interviewees with Indian origin shared difficulties obtaining documents from the Nepali State.

Some interviewees of Tibetan origin stated they were refugees in Nepal and having left their nation forcefully; they did not have any legal documents except 'Refugee Card,' which some of them got in Nepal. They expressed that not having any identification document forced them to use any means, including illegal ones, to obtain Nepalese Citizenship, as shared in the excerpts below:

We paid around 40,000 Nepali Rupees to get signature from C.D.O. We didn't want to complicate things. Compared to my other Tibetan friends, I think I paid very less. (Pema)

They try to get a lot of money from Tibetans. I have heard the Tibetan pay hefty sums of money to Government officials. Many Tibetans easily give money to get the job done faster rather. So, the [Nepalese] Government Officials try and get money from them purposefully. (Lek)

Pema shared that she knew people who got Citizenship by changing their name, surname, father or mother's name, family details, etc. Two of the interviewees, including Pema herself, admitted to changing their identities in their Citizenship certificate:

I changed my name and added surname for the citizenship. It was Lama. (Pema)

An old Nepali man we knew helped my brother and me to get Nepalese Citizenship claiming [we were] his children. His name is in my Citizenship as the father. Most of my family members own Citizenship. I don't know where the old man lives exactly, but he is from Kathmandu. (Kartok)

Moreover, interviewees of Tibetan origin experienced various problems while getting Citizenship, such as the official's delay and discomfort. 
Despite having legal documents in my hand, they can recognize that I was not originally a Nepalese. Officials procrastinating work is the biggest problem that I faced. (Pema)

My mother also has a naturalized Citizenship. So, I will get Citizenship by descent. But I don't yet have a Citizenship... I was told [in Lumbini] that the new constitution has provisions for me to get Citizenship, but it is not yet in practice, so they asked me to come later. (Lek)

In contrast to the above, Anamika held two citizenships -from Nepal and India. However, Nepal doesn't allow dual citizenship. Anamika got Nepali Citizenship through her father and Indian Citizenship through her husband when she married an Indian national. Anamika shared:

Initially, I had a Nepali Citizenship. After marriage, I hold an Indian Citizenship because I was married to an Indian guy...But I feel it was easier back then to get Nepali Citizenship. Now it would have been a more difficult job.

Under the Nepal Citizenship Act, 2006, a person born in Nepal before mid-April 1990, has a permanent domicile and has been continuously resident in Nepal throughout his life, can apply to acquire Citizenship of Nepal based on birth (Nepal Law commission, n.d.). However, many immigrants from India are yet to benefit from this law. For example, Priti's parents could not succeed in receiving a Nepalese Citizenship despite living in Nepal for more than 35 years and meeting other criteria. The interviewees shared that many Indians married Nepali women and bore and brought up children in Nepal, but these children are yet to receive Nepali Citizenship. For example, Priti expressed:

I have Indian Citizenship. My parents still have Indian Citizenship. Even after living in Nepal for 35 years, they could not get Nepali citizenship. I studied here in Nepal, and there is recorded evidence of that. But the 
Nepali government has not yet issued a Citizenship to my parents, let alone me or my sibling. (Priti)

Akash also shared difficulties in obtaining Nepali Citizenship. He shared about arguing multiple times with government officials that he should get Citizenship in Nepal as per the laws, but the officials denied it. Akash shared:

When I was 19, I went to the local government officials to discuss Citizenship...I told him that I fulfilled all the criteria to obtain Citizenship.

But the officer replied that though I fulfilled all the requirements according to the constitution, I would not be given Citizenship unless I was a celebrity or unless I could help Nepal significantly financially. He said - we have 30 lakhs Indian in Nepal, and we cannot give Citizenship to all of them.

The response of the Nepali Government official, as shared by Akash, reflects the general perspective of the State towards immigrants with an Indian origin living in Nepal.

\section{Conclusion}

From the narratives of second-generation migrants, the study illustrates that people of Indian origin were attracted to Nepal for business purposes, good education, and preferable weather. In contrast, immigrants of Tibetan origin had primarily fled to Nepal due to the unstable political scenario of Tibet. Pull factors like favourable climate, religious openness, and business possibilities lured some immigrants to convert the short-term stays into permanent residence. Indian immigrants expressed strong bonds with relatives, e.g., grandparents, cousins, siblings. They shared visiting families in their country of origin frequently as compared to Tibetan migrants. Interviewees shared mixed experiences (both encouraging and humiliating) at school and their interaction with the broader society (both supportive and conflicting). Furthermore, all interviewees shared challenges in dealing with or receiving help from the Nepali State. 


\section{References}

Bhugra, D. (2004). Migration, distress and cultural identity. British Medical Bulletin, 69(1), 129-141. https://doi.org/10.1093/bmb/ldh007

Bhugra, D., Watson, C., \& Ventriglio, A. (2020). Migration, cultural capital and acculturation. International Review of Psychiatry, 33(1-2) 126-131. https://doi.org/10.1080/09540261.2020.1733786

Braun, V., \& Clarke, V. (2012). Thematic analysis. In H. Cooper (Ed.), APA handbook of research methods in Psychology: Vol. 2. Research designs (pp. 57-71). American Psychological Association. https://doi.org/10.1037/13620-004

Central Bureau of Statistics. (2011, May 6). Census data. https://cbs.gov.np/

Global Migration Data Portal. (2019, November 28). Global migration indicators report. https://migrationdataportal.org

Greenfield, E. A., \& Marks, N. F. (2006). Linked lives: Adult children's problems and their parents' psychological and relational well-being. Journal of Marriage and Family, 68(2), 442-454.

Institute of Migration (2019a). Glossary on migration . https://publications.iom.int/system/files/pdf/iml_34_glossary.pdf

Institute of Migration (2019b). Migration in Nepal a country profile 2019. https://publications.iom.int/system/files/pdf/mp_nepal_2019.pdf?language $=\mathrm{en}$

Joseph, K. V. (1988). Migration and economic development of Kerala. Mittal Publications.

Kok, P. (1997). The definition of migration and its application: Making sense of recent South African census and survey data. Southern African Journal of Demography, 7(1), 19-30. http://www.jstor.org/stable/20853242

Lakey, P. N. (2003). Acculturation: A review of the literature. Intercultural Communication Studies, 12(2), 103-118. 
Lee, E. (1966). A theory of migration. Demography, 3(1), 47-57. http://www.jstor.org/stable/2060063

Mandal, C.K. (2019, August 14). As opportunities for Nepali workers dry up in popular labour destinations, migration numbers dwindle. The Kathmandu Post. https://kathmandupost.com/national/2019/08/14/as-opportunitiesfor-nepali-workers-dry-up-in-popular-labour-destinations-migrationnumbers-dwindle

Nepal Law commission (n.d.). Nepal citizenship act 2063 (2006). https://www.lawcommission.gov.np/en/archives/category/documents/prev ailing-law/statutes-acts/nepal-citizenship-act-2063-2006

Pant, P. \& Nepal, S. (2010). Status of children in Nepal. Central Bureau of Statistics. https://docs.censusnepal.cbs.gov.np/Documents/2a735df9-cd89412c-8e4a-cf137e36bdd7.pdf

Sharma, J. R., \& Sharma, S. (2011). Enumerating migration in Nepal: A review [Working Paper]. Centre for the Study of Labour and Mobility, Social Science Baha. https://www.ceslam.org/uploads/backup/Survey Migration History Nepa 1.pdf

Shrestha, N. R. (1990). Landlessness and migration in Nepal. Routledge. https://doi.org/10.4324/9780429042690

United Nations Development Program. (2020). The next frontier: Human development and the anthropocene briefing note for countries on the 2020 human development report Nepal. Human Development Report 2020. http://hdr.undp.org/sites/all/themes/hdr theme/country-notes/NPL.pdf

Virupaksha, H. G., Kumar, A., \& Nirmala, B. P. (2014). Migration and mental health: An interface. Journal of Natural Science, Biology and Medicine, 5(2), 233-239. https://doi.org/10.4103/0976-9668.136141 
Wolpert, J. (1965). Behavioral aspects of the decision to migrate. Papers of the Regional Science Association, 15(1), 159-169.

Yun Kim, Y. (1979). Toward an interactive theory of communicationacculturation. Annals of the International Communication Association, 3 (1), 435-453. 